\title{
Granulocyte and monocyte surface membrane markers in the myelodysplastic syndromes
}

\author{
RE CLARK, TG HOY, A JACOBS \\ From the Department of Haematology, University of Wales College of Medicine, Heath Park, Cardiff
}

SUMMARY The expression of lineage specific surface antigens on granulocytes and monocytes was quantitated using monoclonal antibodies in 16 healthy adults and 21 patients with myelodysplastic syndromes. In nine of 19 patients the granulocytes showed a decrease in myeloid or an increase in monocyte antigen expression or both. In 11 of 19 patients the monocytes showed a decreased expression of monocyte antigens or an increase in myeloid antigens or both.

The data suggest that in the myelodysplastic syndromes the granulocyte-macrophage progenitors do not develop along two divergent lines but differentiate with the emergence of dual characteristics.

In the myelodysplastic syndromes (MDS) there are not only abnormalities of granulocyte morphology, enzyme patterns,' and phagocytosis, ${ }^{2}$ but in vitro colony formation from granulocyte-macrophage precursors (CFU-GM) is also abnormal. ${ }^{3}$ Maturing myeloid cells express a variety of surface proteins specific for their lineage; study of the cells using monoclonal antibodies has shown that their expression may vary during maturation. ${ }^{4} \mathrm{~A}$ recent study of bone marrow cells from three patients with primary acquired sideroblastic anaemia showed that the granulocytes were abnormally sensitive to complement mediated lysis by an antibody to mononuclear cells, ${ }^{5}$ which suggests the presence of inappropriate surface antigens in this condition. This paper examines the expression of lineage specific surface markers on peripheral blood monocytes and granulocytes in MDS.

\section{Subjects and methods}

\section{SUBJECTS}

Sixteen healthy subjects were investigated. These were members of the laboratory staff or patients admitted to hospital for minor eye surgery who were otherwise healthy and were not taking medication. There were nine men and seven women with an age range of 25-84 years (mean 61.5). Twenty one patients (nine men and 12 women) with MDS were also studied. Their age range was $29-87$ years (mean 56.4 years), and they included seven patients with

Accepted for publication 29 November 1984 sideroblastic anaemia, six with refractory anaemia, four with refractory anaemia with excess blasts, one with refractory anaemia with excess blasts in transformation, two with idiopathic macrocytosis, and one with chronic myelomonocytic leukaemia. Table 1 shows their haematological characteristics.

\section{METHODS}

Phosphate buffered saline, $\mathrm{pH} 7 \cdot 3$, with $2 \%$ bovine serum albumin and $0.02 \%$ sodium azide was used for washing and suspending cells. Twenty millilitres of venous blood was anticoagulated with $15 \mathrm{U} / \mathrm{ml}$ preservative free heparin. White cell separation was performed by centrifugation through FicollHypaque (specific gravity 1.077 ) at $400 \mathrm{~g}$ at room temperature for $30 \mathrm{~min}$. The granulocyte and red cell rich pellet was resuspended in a mixture of equal volumes of Dextran 150 and buffer and allowed to sediment for $90 \mathrm{~min}$ at room temperature to reduce red cell contamination of the mononuclear cells. Samples containing more than $90 \%$ red cells, assessed using a Coulter ZF Channelyser, were discarded. Both the resulting granulocyte rich supernatant and the mononuclear cell layer from the original Ficoll-Hypaque separation were washed twice in buffer and the cell concentration was adjusted to $4 \times 10^{10} / 1$. All preparations were examined microscopically after Jenner-Giemsa staining and granulocyte preparations with more than $2 \%$ mononuclear cell contamination or mononuclear preparations containing more than $3 \%$ granulocytes were discarded. No granulocyte preparation contained more than $5 \%$ eosinophils. 
Table 1 Haematological data in patients with myelodysplastic syndromes

\begin{tabular}{|c|c|c|c|c|c|}
\hline $\begin{array}{l}\text { Patient } \\
\text { no }\end{array}$ & $\begin{array}{l}\text { Haemoglobin } \\
\text { concentration } \\
\text { (g/dl) }\end{array}$ & $\begin{array}{l}\text { Polymorphonuclear } \\
\text { leucocyte count } \\
\left(\times 10^{9} / l\right)\end{array}$ & $\begin{array}{l}\text { Monocyte count } \\
\left(\times 10^{9} l l\right)\end{array}$ & $\begin{array}{l}\text { Platelet count } \\
\left(\times 10^{9} / l\right)\end{array}$ & $\begin{array}{l}\text { Agranular } \\
\text { polymorphonuclear } \\
\text { leucocytes }\end{array}$ \\
\hline $\begin{array}{l}1 \\
2 \\
3 \\
4 \\
5 \\
6 \\
7 \\
8 \\
9 \\
10 \\
11 \\
12 \\
13 \\
14 \\
15 \\
16 \\
17 \\
18 \\
19 \\
20 \\
21\end{array}$ & $\begin{array}{r}12.0 \\
11.9 \\
8.5 \\
8.8 \\
11.0 \\
9.3 \\
10.5 \\
7.2 \\
15.2 \\
9.6 \\
12.1 \\
12.7 \\
13.5 \\
13.0 \\
10.5 \\
10.8 \\
13.2 \\
10.8 \\
12.5 \\
11.6 \\
11.1\end{array}$ & $\begin{array}{l}4.4 \\
8.2 \\
7.5 \\
1.1 \\
1.9 \\
3.1 \\
2.0 \\
3.7 \\
4.6 \\
3.6 \\
0.9 \\
0.05 \\
4.6 \\
1.8 \\
0.46 \\
1.9 \\
2.0 \\
1.9 \\
2.4 \\
0.25 \\
0.8\end{array}$ & $\begin{array}{l}0.31 \\
0.09 \\
0.93 \\
0.19 \\
0.53 \\
0.18 \\
0.22 \\
1.78 \\
0.21 \\
0.55 \\
1.16 \\
0.50 \\
0.85 \\
0.42 \\
0.02 \\
0.16 \\
0.66 \\
0.11 \\
0.30 \\
0.50 \\
1.08\end{array}$ & $\begin{array}{r}270 \\
121 \\
467 \\
130 \\
175 \\
282 \\
117 \\
106 \\
156 \\
46 \\
109 \\
16 \\
132 \\
46 \\
109 \\
55 \\
287 \\
42 \\
21 \\
204 \\
43\end{array}$ & $\begin{array}{l}0 \\
+ \\
++ \\
0 \\
0 \\
0 \\
0 \\
0 \\
0 \\
0 \\
0 \\
\text { ND } \\
0 \\
0 \\
0 \\
0 \\
+ \\
+++ \\
0 \\
+ \\
0\end{array}$ \\
\hline
\end{tabular}

The monoclonal antibodies used were the myeloid specific $82 \mathrm{H} 1$ and $82 \mathrm{H} 6$, kindly donated by $\mathrm{Dr}$ Janowska-Wieczorek, ${ }^{6}$ and the monocyte specific Mo2 ${ }^{7}$ and FMC $17 .{ }^{8}$ Nucleated cells $\left(2 \times 10^{6}\right)$ were incubated with each of the monoclonal antibodies for $30 \mathrm{~min}$ at $4^{\circ} \mathrm{C}$, washed twice in buffer, resuspended, and incubated for $30 \mathrm{~min}$ at $4^{\circ} \mathrm{C}$ with fluorescein-isothiocyanate conjugated rabbit antimouse Fab fragment. Controls were not incubated with the first monoclonal antibody. Cells were again washed twice in buffer and fixed in an equal volume of $4 \%$ paraformaldehyde, $\mathrm{pH} 7 \cdot 3$.

Fluorescence was analysed using a FACS-III (Becton-Dickinson) with a $4 \mathrm{~W}$ argon ion laser emitting at $488 \mathrm{~nm}$. At least $5 \times 10^{3}$ cells were analysed. In the granulocyte fractions contaminating erythrocytes were excluded from the analysis by appropriate setting of a forward light scatter window and no difficulty was encountered in defining a granulocyte peak in any of the cases studied. In the mononuclear cell fraction a monocyte shoulder was identifiable on the forward light scatter distribution in nearly all cases studied. We restricted analysis of the mononuclear layer to cells in or larger than this monocyte shoulder by the use of appropriate gating. Fluorescence was standardised using fluorescent beads (Polysciences Ltd).

Fluorescence histograms were analysed with an

Table 2 Percentage positive cells after incubation with myeloid or monocyte specific monoclonal antibodies: healthy subjects

\begin{tabular}{|c|c|c|c|c|c|c|c|c|}
\hline \multirow[t]{2}{*}{ Subject no } & \multicolumn{4}{|c|}{ Granulocytes } & \multicolumn{4}{|c|}{ Large mononuclear cells } \\
\hline & $H 1$ & H6 & Mo2 & $F M C 17$ & HI & H6 & Mo2 & FMC17 \\
\hline $\begin{array}{l}22 \\
23 \\
24 \\
25 \\
26 \\
27 \\
28 \\
29 \\
30 \\
31 \\
32 \\
33 \\
34 \\
35 \\
36 \\
37 \\
\text { Range }\end{array}$ & $\begin{array}{l}77 \\
68 \\
83 \\
91 \\
92 \\
86 \\
91 \\
- \\
\overline{93} \\
89 \\
43 \\
= \\
- \\
89 \\
43-93\end{array}$ & $\begin{array}{l}86 \\
72 \\
84 \\
96 \\
98 \\
90 \\
97 \\
85 \\
92 \\
97 \\
50 \\
94 \\
67 \\
- \\
79 \\
50-97\end{array}$ & $\begin{array}{r}5 \\
4 \\
11 \\
5 \\
7 \\
2 \\
5 \\
3 \\
2 \\
8 \\
6 \\
8 \\
\frac{12}{-5} \\
2-11\end{array}$ & $\begin{array}{r}3 \\
3 \\
10 \\
3 \\
8 \\
3 \\
2 \\
9 \\
9 \\
4 \\
3 \\
11 \\
3 \\
3 \\
= \\
2-11\end{array}$ & $\begin{array}{c}7 \\
5 \\
5 \\
10 \\
2 \\
8 \\
- \\
- \\
-7 \\
4 \\
11 \\
4 \\
10 \\
7 \\
9 \\
2-11\end{array}$ & $\begin{array}{l}6 \\
1 \\
5 \\
9 \\
3 \\
9 \\
-9 \\
7 \\
5 \\
7 \\
9 \\
5 \\
8 \\
11 \\
10 \\
1-11\end{array}$ & $\begin{array}{l}32 \\
26 \\
22 \\
71 \\
31 \\
54 \\
\frac{48}{61} \\
14 \\
51 \\
69 \\
44 \\
\frac{15}{40} \\
14-71\end{array}$ & $\begin{array}{l}44 \\
41 \\
65 \\
64 \\
64 \\
39 \\
\frac{65}{65} \\
68 \\
68 \\
58 \\
77 \\
71 \\
75 \\
34 \\
76 \\
34-77\end{array}$ \\
\hline
\end{tabular}


Table 3 Percentage positive cells after incubation with myeloid or monocyte specific monoclonal antibodies: patients with myelodysplastic syndromes

\begin{tabular}{|c|c|c|c|c|c|c|c|c|}
\hline \multirow[t]{2}{*}{ Patient no } & \multicolumn{4}{|c|}{ Granulocytes } & \multicolumn{4}{|c|}{ Large mononuclear cells } \\
\hline & $H 1$ & H6 & $M o 2$ & $F M C 17$ & $H 1$ & H6 & $M o 2$ & $F M C 17$ \\
\hline $\begin{array}{l}1 \\
2 \\
3 \\
4 \\
5 \\
6 \\
7 \\
8 \\
9 \\
10 \\
11 \\
12 \\
13 \\
14 \\
15 \\
16 \\
17 \\
18 \\
19 \\
20 \\
21\end{array}$ & $\begin{array}{l}90 \\
90 \\
41^{*} \\
85 \\
-\overline{92} \\
84 \\
45 \\
92 \\
86 \\
78 \\
14^{*} \\
79 \\
61 \\
19 * \\
16^{*} \\
87 \\
3^{*} \\
86 \\
64\end{array}$ & $\begin{array}{l}94 \\
84 \\
40^{*} \\
91 \\
\frac{1}{95} \\
84 \\
63 \\
95 \\
92 \\
79 \\
21^{*} \\
87 \\
79 \\
15^{*} \\
72 \\
88 \\
5^{*} \\
81 \\
67\end{array}$ & $\begin{array}{c}14^{*} \\
59^{*} \\
9 \\
3 \\
- \\
4 \\
6 \\
12^{*} \\
8 \\
7 \\
5 \\
2 \\
5 \\
3 \\
9 \\
2 \\
15^{*} \\
4 \\
-5\end{array}$ & $\begin{array}{c}21^{*} \\
21^{*} \\
6 \\
4 \\
- \\
- \\
- \\
20^{*} \\
4 \\
- \\
- \\
-15^{*} \\
-5 \\
13^{*} \\
5 \\
23^{*} \\
- \\
6\end{array}$ & $\begin{array}{c}1 \\
13^{*} \\
35^{*} \\
33^{*} \\
6 \\
11 \\
13^{*} \\
-3 \\
36^{*} \\
5 \\
10 \\
4 \\
10 \\
-7 \\
7 \\
23^{*} \\
12^{*} \\
2 \\
9\end{array}$ & $\begin{array}{c}4 \\
15^{*} \\
39^{*} \\
42^{*} \\
5 \\
12^{*} \\
13^{*} \\
- \\
3 \\
36^{*} \\
7 \\
7 \\
10 \\
9 \\
- \\
4 \\
7 \\
22^{*} \\
12^{*} \\
8 \\
9\end{array}$ & $\begin{array}{c}38 \\
69 \\
39 \\
54 \\
49 \\
45 \\
19 \\
- \\
1^{*} \\
15 \\
12^{*} \\
25 \\
74 \\
29 \\
- \\
- \\
21 \\
24 \\
46 \\
23\end{array}$ & $\begin{array}{l}45 \\
55 \\
33^{*} \\
56 \\
59 \\
71 \\
66 \\
-7^{*} \\
16^{*} \\
51 \\
29^{*} \\
81 \\
64 \\
65 \\
81 \\
16^{*} \\
56 \\
76 \\
78\end{array}$ \\
\hline
\end{tabular}

*Indicates loss of lineage specific antigen or increased expression of inappropriate antigens.

Apple II microcomputer and homemade software. An arbitrary fluorescence value was found at which the control cell suspension gave not more than $5 \%$ positive cells. Any cells more fluorescent than this value with test antisera were then taken to be positive. ${ }^{9}$

\section{Results}

Table 2 shows the percentage of positive cells for 16 healthy subjects using each antibody. In a few cases cell preparations were inadequate for study. The results were not related to age or sex. Neither granulocytes nor mononuclear cells showed more than $11 \%$ positivity with the inappropriate antibodies. Mo2 antigen seemed more variable in its expression on monocytes than FMC 17.

The results in MDS patients are shown in Table 3, and in this group too there was no relation to age or sex. In the granulocyte fractions five of 19 patients showed reduced positivity with myeloid monoclonal antibodies; in four cases this occurred with both antibodies. Six of 14 patients showed an increase in positivity with the monocyte monoclonal antibodies; in four with both antibodies. Abnormal expression of lineage determinants on granulocytes was found in a total of nine of 19 patients. In only two cases was an abnormal decrease in myeloid determinants associated with an abnormal increase in monocyte determinants. There did not appear to be any clear relation with the peripheral blood neutrophil count, the presence of agranular neutrophils, or an abnor- mal monocyte count.

In the mononuclear cell fractions 11 of 19 patients showed an abnormality of lineage determinants: eight showed increased reactivity with myeloid specific monoclonal antibodies and six showed reduced reactivity with monocyte monoclonal antibodies. Abnormal reactivity of mononuclear cells was not necessarily associated with abnormalities in the granulocyte fraction. A total of 16 of the 21 patients showed some abnormality of antigen expression (Table 3 ).

\section{Discussion}

The multiple abnormalities in granulocyte function described in patients with dysplastic marrow ${ }^{210}$ appear to represent an aberration of myeloid differentiation. The observations of Scott $e t a l^{\prime}$ that granulocytes in this condition may contain increased concentrations of monocyte isoenzymes suggest the possibility of misprogramming in the differential gene activation associated with the development of myeloid and monocytic cells from a common precursor. The absence of monocyte antigenic characteristics of the granulocytes in their study, determined with the monoclonal antibody 63D3, does not support this possibility. In an earlier study, ${ }^{5}$ however, the susceptibility of granulocytes in some patients with idiopathic sideroblastic anaemia to lysis by an antimononuclear cell antibody suggests that differentiation of granulocyte-macrophage progenitors is disordered. The finding of inappropriate enzymes 
in the granulocytes of patients with megaloblastic anaemia due to vitamin $B_{12}$ or folate deficiency' suggests that this phenomenon is not necessarily related to an irreversible genetic lesion.

In the present study the myeloid specific antibodies used were $82 \mathrm{H} 1$ and $82 \mathrm{H} 6$. These antibodies recognise two distinct antigens appearing at the myeloblast/promyelocyte stage, that for $82 \mathrm{H6}$ appearing somewhat earlier than $82 \quad \mathrm{H}^{6}$ (Janowska-Wieczorek, personal communication). Mo2 antibody recognises a monocyte specific antigen, which is not found in granulocytes, erythrocytes, or lymphocytes. It is expressed on blast cells in patients with acute myeloid leukaemia showing monocytic features, but not on U-937, a cell line with monocytic features. ${ }^{7}$ FMC 17 recognises a monocyte specific antigen found on mature monocytes and their precursors but not expressed on tissue macrophages except in the lung"1 and only weakly expressed on the blast cells of some patients with acute myeloid leukaemia. ${ }^{8}$ The results expressed here indicate both a loss of lineage specific antigen and increased expression of an inappropriate antigen on peripheral blood leucocytes in many patients with MDS. There are no obvious differences between the different FAB diagnostic groups but there are too few cases for this to be certain.

The data suggest that in myelodysplastic patients the common granulocyte-macrophage precursor does not develop along two divergent lines as in normal haemopoiesis with differentiation into either myeloid or macrophage cell types; neither does there appear to be a simple failure of differentiation. CFU-GM appear to give rise to cells with the characteristics of both differentiation pathways. We do not know whether aberrant or defective sialation affects accessibility of surface antigenic determinants in a reversible manner or whether we are seeing an irreversible expression of somatic mutation. The epitopes recognised by lineage specific monoclonal antibodies have, in general, not been well characterised. The $82 \mathrm{H} 6$ antibody (though not $82 \mathrm{H1}$ ) identifies the oligosaccharide structure 3-fucosyl $\mathrm{N}$-acetyl-lactosamine, also termed the $\mathrm{X}$-hapten. ${ }^{13}$ The antigen sites identified by FMC17 or Mo2 have not been reported. Expression of the Mo2 antigen is lost after treatment of monocytes with trypsin but is regenerated by overnight culture, a process partially blocked by puromycin.? Neuraminidase treatment had no effect on the degree of expression. It is difficult to link the abnormalities in antigen expression described here to biochemical and molecular events occurring during differentiation. Sieff $e \boldsymbol{a l}^{\mathbf{1}^{12}}$ point out that since monoclonal antibodies detect antigenic determinants of low molecular weightfor example, a few amino acids or sugars - failure to detect an antigen does not necessarily imply absence of the structure with which that antigen is usually associated. Tetteroo et $\mathrm{l}^{14}$ have recently shown that the X-hapten may be detected both on normal monocytes and on acute myeloid leukaemia blasts after but not before neuraminidase treatment. It is intriguing to speculate that in the case of carbohydrate determinants, expression may be linked to maturation related glycosylation or sialation.

This study was supported by the Leukaemia Research Fund.

\section{References}

' Scott CS, Cahill A, Bynoe AG, Ainley MJ, Hough D, Roberts BE. Esterase cytochemistry in primary myelodysplastic syndromes and megaloblastic anaemias: Demonstration of abnormal staining patterns associated with dysmyelopoiesis. Br J Haematol 1983;55:411-8.

${ }^{2}$ Boogaerts MA, Nelissen V, Roelant C, Goossens W. Blood neutrophil function in primary myelodysplastic syndromes. $\mathrm{Br} \mathrm{J}$ Haematol 1983;55:217-27.

${ }^{3}$ Verma DS, Spitzer G, Dicke KA, McCredie KB. In vitro agar culture patterns in preleukaemia and their clinical significance. Leukaemia Res 1979;3:41-9.

${ }^{4}$ Zola H, McNamara P, Thomas M, Smart IJ, Bradley J. The preparation and properties of monoclonal antibodies against human granulocyte membrane antigens. $\mathrm{Br} J$ Haematol 1981;48:481-90.

s Ali FMK, May A, Jones BM, Jacobs A. Enrichment of erythroblasts from human bone marrow using complement mediated lysis: A measurement of ferritin. $\mathrm{Br} J$ Haematol $1983 ; 53: 227-35$.

- Mannoni P, Janowska A, Fromont P, Weiblen B, Turner AR, Turc JM. Human myeloid differentiation studied by monoclonal antibodies. In: Bernard A, Boumsell L, Dausset J, Milstein C, Schlossman SF, eds. Leucocyte typing. Berlin: Springer-Verlag 1984.

' Todd RF, Schlossman SF. Analysis of antigenic determinants on human monocytes and macrophages. Blood 1982;59:775-86.

${ }^{8}$ Brooks DA, Zola H, McNamara PJ, Bradley J, Bradstock KF, Hancock WW, Atkins RC. Membrane antigens of human cells studied with monoclonal antibodies. Pathology 1983;15:4552.

' Kruth HS. Flow cytometry: rapid biochemical analysis of single cells. Anal Biochem 1982;125:225-42.

${ }^{10}$ Martin S, Baldock SC, Ghoneim ATM, Child JA. Defective neutrophil function and microbicidal mechanisms in the myelodysplastic disorders. J Clin Pathol 1983;36:1120-8.

" Hancock WW, Zola H, Atkins RC. Antigenic heterogeneity of human mononuclear phagocytes: Immunohistologic analysis using monoclonal antibodies. Blood 1983;62:1271-9.

${ }^{12}$ Sieff C, Bicknell D, Caine G, Robinson J, Lam G, Greaves MF. Changes in cell surface antigen expression during haemopoietic differentiation. Blood 1982;60:703-13.

${ }^{13}$ Janowska-Wieczorek A, Mannoni P, Krantz MJ, Turner AR, Turc JM. Inhibition of CFU-GM, BFU-E, CFU-GEMM colony formation by monoclonal antibodies from the myeloid panel. Proceedings of the 2nd leucocyte typing workshop (in press).

${ }_{14}$ Tetteroo PAT, Van T Veer MB, Tromp JF, Von dem Borne AEG. Detection of the granulocyte-specific antigen 3-fucosyl-N-acetyl-lactosamine on leukaemic cells after neuraminidase treatment. Int J Cancer 1984;33:355-8.

Requests for reprints to Professor A Jacobs, Department of Haematology, University of Wales College of Medicine, Heath Park, Cardiff. 